ISBN 87-7882-012-X (trykt)

ISBN 87-7882-013-8 (online)

WORKING PAPER 04-15

Jan Bentzen, Erik Strøjer Madsen, Valdemar Smith and Mogens Dilling-Hansen

Persistence in Corporate Performance?

- Empirical Evidence from Panel Unit Root Tests

Department of Economics

Aarhus School of Business 


\title{
Persistence in Corporate Performance? Empirical Evidence from Panel Unit Root Tests
}

\author{
Jan Bentzen* \\ Erik Strøjer Madsen \\ Valdemar Smith \\ Department of Economics \\ Aarhus School of Business \\ $\&$ \\ Centre for Industrial Economics \\ Denmark \\ Mogens Dilling-Hansen \\ Department of Economics \\ University of Aarhus \\ $\&$ \\ Centre for Industrial Economics \\ Denmark
}

\begin{abstract}
:
Persistence in corporate performance is analyzed in the framework of empirical tests of unit root behavior concerning firm profits. Data for firm-specific rates of return is applied in a set of panel unit root tests to address the question of persistence in profits both at firm level and for the aggregate level of industry-specific profits. The firm data all reject a null hypothesis of random walk behavior of profits but when smoothing profit rates at a two-digit NACE-code level for industries, the empirical evidence is more mixed as most industries show up with a unit root in aggregate rates of return, i.e. indicating persistence in corporate performance.
\end{abstract}

Keywords: Corporate performance; Persistence in profits; Panel unit root tests JEL codes: C3, L2

\footnotetext{
* Mailing address: Department of Economics, Aarhus School of Business, Prismet $7^{\text {th }}$ floor, Silkeborgvej 2, DK-8000 Aarhus C, Denmark. Email: jb@asb.dk
} 


\section{Introduction}

In the field of corporate performance within the industrial organization economics literature, studies by Mueller (1977, 1986, 1990) and Geroski and Jacquemin (1988) have initiated a whole body of literature dealing with the question of persistence in firm profitability. A vast number of empirical studies have been initiated in order to verify the basic idea that profits deviating from normal profit or normal rent will vanish over time. Profits may be specific to industries where also entry barriers in many cases are present along other forces restricting competition - but in the long run competitive forces are assumed to alleviate the level of profits among firms and industries towards some normal rate of return. In the empirical analysis, dynamic models relying on some kind of autoregressive formulation are usually applied assuming a time-convergence process where abnormal profits are eroded away. A summary of earlier studies of persistence in profits is presented in e.g. Lipczinsky and Wilson (2001) and the empirical findings are somewhat mixed as also evidence of long-run profits beyond normal profits are found.

Many of the empirical studies related to the persistence of profits literature apply panel data sets related to firms which also will be used in the present analysis, but the empirical modeling and testing procedure will differ. The latter concerns the application of panel unit root tests to the data for firm profits - as well as industry-specific rates of returns as the hypothesis to test is whether profits behave as a random walk process or not. Many economic and financial variables show up in empirical tests with a unit root, i.e. a nonstationary behavior, and a priori there should be no reason to exclude the same timeseries properties of firm profits. Hence, rates of return related to both firms and industries are investigated with respect to a unit root using panel data covering several thousand Danish firms. In case a unit root is found, this is evidence of persistence in profits defined as a random walk process where the best forecast of next period's profit is the present level of profit. Therefore, if profits do contain a unit root, there can be no mean-reverting process towards some level of 'normal profit', indicating that further empirical modeling of firm profits has to take into consideration the non-stationary behavior of profits. Consequently, the unit root concept is presented in part two, followed by an introduction 
of recent developments in panel unit root tests that are to be applied in the empirical analysis. The data sources are shortly explained in section three and the empirical results for firms and industries are found in sections four and five, respectively. Section six concludes the analysis.

\section{Modeling persistence in corporate profits}

The degree of corporate performance is usually measured by various firm-specific rates of profit. One straightforward assumption for the time path of profits is that this might be a random walk process like for example stock prices that are often found to be nonstationary I(1)-variables and hence non-predictable. Firm profits are among the most important sets of variables influencing stock prices, and therefore it is obvious to model and test profits for random walk behavior. As profits are measured as a rate of return, the most obvious model is a random walk without drift as given by (1):

$$
\pi_{t}=\pi_{t-1}+\varepsilon_{t} \quad \varepsilon_{t}: N\left(0, \sigma^{2}\right)
$$

The solution to the difference equation is (2):

$$
\pi_{t}=\pi_{0}+\sum_{i=1}^{t} \varepsilon_{i}
$$

All shocks have permanent effects on profits, and furthermore (3) and (4) hold, indicating that the variance is time-dependant:

$E_{t}\left(\pi_{t+1}\right)=\pi_{t}$

$\operatorname{Var}\left(\pi_{t}\right)=\operatorname{Var}\left(\varepsilon_{1}+\ldots+\varepsilon_{t}\right)=t \sigma^{2}$

This model is directly applicable to empirical tests and has been applied in numerous fields of economics, e.g. when testing purchasing power parities or investigating the time-series properties of many other macroeconomic variables.

The empirical models used in most studies of corporate performance go back to the studies of Mueller $(1977,1986)$ who have founded a whole body of literature dealing with the dynamics of company profits. This literature, which has also become known as 'the persistence of profits literature', includes studies by e.g. Geroski and Jacquemin 
(1988), Schwalbach et al. (1989), Mueller (1990), Cubbin and Gerosky (1987), Jenny and Weber (1990), Odagiri and Yamawaki (1990), Schol (1990), Cubbin and Geroski (1990), Goddard and Wilson (1996), Waring (1996) and Yurtoglu (2004). However, except for the study of Yurtoglu (2004), these studies differ from the unit root approach as they can be presented in a stylized or reduced form by (5):

$\pi_{t}=r+s_{t}$

Profits consist of an element of competitive return (r). In Mueller (1990) this is divided into both a return common to all firms and a firm-specific rent component, which for the sake of simplicity appears as a single term in (5), which is also without the notation for the cross-section dimension of the panel data most often used in these studies.

The second term in (5) is some short-run rent that is assumed to decay over time and is indicated by the $\lambda$-parameter in (6):

$s_{t}=\lambda s_{t-1}+\varepsilon_{t}$

Assuming the absolute value of $\lambda$ is less than one, the model reduces quickly to an ARmodel where the $\lambda$-parameter as well as the long-term profit can be modeled and subsequently estimated. Hence, with no restrictions on the model given by (5) and (6) the reduced form is given by:

$\pi_{t}=(1-\lambda) r+\lambda \pi_{t-1}+\varepsilon_{t}$

However, if there is a unit root component in profits - i.e. with $\lambda=1$ in (6) - then the model in (7) will develop as a random walk - similar to equation (1) - and further modeling is inappropriate unless these time-series properties of the data are explicitly dealt with. In most of the empirical studies mentioned above, the $\lambda$-parameter is estimated and typically with $\lambda$-values ranging between 0.2 and 0.66 , see Mueller (1990) and Waring (1996), indicating that profits are not persistent. However, none of these studies, except Yurtoglu (2004), discusses potential problems associated with nonstationarity of the data employed or the need for unit root tests. 
Therefore, whether or not profits behave as a stationary process is an empirical question to answer in the persistence of profits studies. The empirical test of persistence in firm profits will consequently be done from a null hypothesis of unit root behavior as in (8):

$$
H_{0}: \lambda=1 \quad \Delta \pi_{t}=\varepsilon_{t}
$$

A major problem when using firm-specific data is often the lack of a sufficiently long time-series dimension in the available data sets why several empirical studies rely on panel data - this is also the case in the present analysis. According to the methodology developed by Im et al. (2003) - IPS in the following - used when testing for a unit root in panel data and adopted to the topic of firm profits can be modeled according to the assumptions from part 2:

$$
\pi_{i, t}=\left(1-\lambda_{i}\right) r_{i}+\lambda_{i} \pi_{i, t-1}+\varepsilon_{i, t} \quad i=1, \ldots, N \quad t=1, \ldots, T
$$

The number of panel members is $\mathrm{N}$ and the empirical application is usually estimated as:

$$
\begin{aligned}
& \Delta \pi_{1, t}=\alpha_{1}+\beta_{1} \pi_{1, t-1}+\sum_{j=1}^{m_{1}} \gamma_{1, j} \Delta \pi_{1, t-j}+\varepsilon_{1, t} \\
& \vdots \\
& \Delta \pi_{N, t}=\alpha_{N}+\beta_{N} \pi_{N, t-1}+\sum_{j=1}^{m_{N}} \gamma_{N, j} \Delta \pi_{N, t-j}+\varepsilon_{N, t}
\end{aligned}
$$

Where the null hypothesis in the IPS-test is:

$$
H_{0}: \forall \beta_{i}=0 \quad i=1, \ldots, N
$$

The alternative is that at least one cross-sectional unit does not have a unit root. This is a drawback of this test as no information is revealed as to which panel members contain a unit root, see also Strauss and Yigit (2003) for further comments on potential problems with panel unit root tests. Yet, one of the advantages compared to other methods is that the autoregressive coefficients may vary among the cross-sectional units and the test has more power than single-equation Dickey-Fuller tests (ADF). The test is done as a single equation ADF-test with the test-statistic as an average $t$-value where critical values for varying panel sizes with respect to $\mathrm{N}$ and $\mathrm{T}$ are tabulated in Im et al. (2003).

When dealing with panel data, it is, of course, of great importance to identify the firm performances containing a unit root. This can be done in the so-called SURADF-test, presented in Breuer et al. $(2001,2002)$, which therefore also will be applied in the 
empirical analysis. The model is of the same form as (10) and estimated as a SUR system, but with individual tests of a unit root null hypothesis for each panel member, where the alternative $\left(\mathrm{H}_{\mathrm{I}}\right)$ is stationarity:

$$
\begin{aligned}
& H_{0,1}: \beta_{1}=0 \quad H_{I, 1}: \beta_{1}<0 \\
& H_{0, N}: \beta_{N}=0 \quad H_{I, N}: \beta_{N}<0
\end{aligned}
$$

Like in other tests, critical values are derived from simulations taking into consideration the actual panel data and the estimated covariance matrix from these data. ${ }^{1}$ The basic advantage of the SURADF-model is then to be able to specify which firms that most likely - taking the power of the test into consideration - can be characterized as having a unit root in the data series.

\section{Data for corporate performance}

Data for corporate performance derives from a private company, Kobmandsstandens Oplysningsbureau, that collects data from annual account reports which Danish firms are obliged to submit to the authorities. This database includes information concerning industry codes (NACE-codes) as well as a lot of economic variables related to the specific firms. In the analysis below - which is based on data at the firm level performance is measured by the accounting rate of profit on sales.

The first part of the empirical analysis relates to firm-specific data and these have been extracted from the database using a rather strong criterion of no missing information with regard to a range of relevant accountancy information. Thereby, a sub-sample of firms supplying 'reliable data' has been selected as a lot of firms have missing values in their

\footnotetext{
${ }^{1}$ See e.g. the panel unit root test by Taylor and Sarno (1998a, 1998b). It is a multivariate Dickey-Fuller test (MADF) where the system of equations (10) is estimated by the seemingly unrelated regression techniques (SUR). The test allows for different autoregressive coefficients across panel members but also for contemporaneous error correlations across the panel. The null hypothesis is similar to the IPS-test and is done by a joint test for the $\mathrm{N} \beta$-parameters as stated in (11), and the alternative hypothesis is again that not all panel members contain a unit root. The critical values for the MADF-test has to be derived from simulations as these depend upon the estimated covariance matrix as well as the number of panel members (N) and sample size, cf. Dreger and Kosfeld (2003), Wagner (2003), Breuer et al. (2001, 2002), Österholm (2004), which also serve as survey articles for recent developments in panel unit root tests.
} 
accountancy reports to the authorities. The data set to be used in the analysis consists of 1310 firms over the time period 1990-2001. ${ }^{2}$

When inspecting the data for the 1310 panel firms, their profit on sales rates fluctuate surprisingly much even on an annual basis. Part of this variation may be caused by institutional factors (e.g. accountancy practices, tax rules, etc.) and does not reflect the true economic performances. Therefore, persistence in profits is also analyzed by calculating the average rate of return for given industries at the two-digit NACE level. These industries are reported in Table 1 and again the profit on sales has been extracted for analysis. ${ }^{3}$ The result is a relatively large number of firms - even within the 18 industries.

This industry data set then consists of a balanced panel with $\mathrm{N}=18$ and $\mathrm{T}=12$. However, within the industries the minimum number of firms is 70 and in most of the cases several hundreds of observations are available in each industry. Therefore, the industry average profit on sales rates is not sensitive to fluctuations concerning performances of the individual firms, and the subsequent use of these aggregate data might more efficiently reveal any signs of persistence in corporate performance compared to the more 'erratic' nature of firm data. Thus, if firms within an industry have succeeded in setting up effective barriers of entry, strong persistence in profits is expected to be present.

\footnotetext{
${ }^{2}$ In order to eliminate extreme observations, which could affect the results, firms with rates of return exceeding 100 percent in absolute value have been deleted from the data set. In most cases, such a variation is caused by special accountancy procedures and is not reflecting real economic activity.

${ }^{3}$ The only other restrictions applied when extracting the data at the industry level is that the rate of profit on sales (in percent of turnover) is below 50 percent (in absolute value, and like before in order to avoid outliers due to the accountancy rules) and that data for profits are available for the whole sample period 1990-2001.
} 
Table 1. Industry data: Number of firms in the data sample of 18 industries and average annual rates of return, 2001.

\begin{tabular}{lllll}
\hline $\mathrm{N}$ & & NACE-codes & $\begin{array}{l}\text { Number } \\
\text { of firms }\end{array}$ & $\begin{array}{l}\text { Profit on sales } \\
\text { rates }\end{array}$ \\
\hline 1 & Primary industries & {$[0 ; 15[$} & 675 & 0.099 \\
2 & Food, beverages & {$[15 ; 17[$} & 215 & 0.061 \\
3 & Textiles & {$[17 ; 19[$} & 86 & 0.041 \\
4 & Footwear, wood products & {$[19 ; 21[$} & 69 & 0.044 \\
5 & Paper, printing & {$[21 ; 24[$} & 429 & 0.045 \\
6 & Chemical products & {$[24 ; 25[$} & 98 & 0.165 \\
7 & Rubber and plastic products & {$[25 ; 26[$} & 103 & 0.050 \\
8 & Non-metallic mineral products & {$[26 ; 27[$} & 76 & 0.045 \\
9 & Basic metals & {$[27 ; 29[$} & 353 & 0.049 \\
10 & Machinery and equipment & {$[29 ; 30[$} & 291 & 0.044 \\
11 & Electrical equipment & {$[30 ; 34[$} & 259 & 0.056 \\
12 & Transport equipment & {$[34 ; 36[$} & 70 & 0.041 \\
13 & Furniture, toys & {$[36 ; 40[$} & 144 & 0.058 \\
14 & Energy, construction & {$[40 ; 50[$} & 2176 & 0.043 \\
15 & Whole- and retail sales, repair & {$[50 ; 60[$} & 4667 & 0.073 \\
16 & Transport services & {$[60 ; 65[$} & 1001 & 0.172 \\
17 & Financial services, consultants & {$[65 ; 75[$} & 7372 & 0.080 \\
18 & Public regulation and social service & {$[75 ; 99[$} & 1453 & 0.081 \\
\hline
\end{tabular}

Note: Only firms with rates of returns within the interval $[-50 \% ;+50 \%]$ are included in the data sample. The rate of profit on sales is defined as the ratio between the accounting profit related to primary activities and turnover.

\section{Testing for persistence in firm performances}

The panel data for firm-specific rates of return has 1310 panel members which eliminates the possibility of applying the SURADF methodology due to the short time span of only 12 observations - with this short time span only a few panel members can be estimated simultaneously by the SUR techniques. Therefore, the IPS unit root test involving each panel member separately is selected for the test of persistence in firm profits. Firstly, the IPS-test is done for the whole panel data set with $\mathrm{N}=1310$ and $\mathrm{T}=12$ where crosssectional means of firm profits are subtracted from the data. This is quite similar to the procedure followed in Mueller (1990) and related studies where rates of return for firms 
are measured as relative deviations from an economy-wide average rate of profit in order to correct for common business cycle factors.

Because of the short time-series dimension of the data set there is also a limit to the number of lags that can be added in the Dickey-Fuller test without consuming too many degrees of freedom. Lags are added on the right-hand side of (10) in order to whiten the errors, and in the test procedure two lags are initially added for all 1310 panel members. The unit root test is then performed as a stepwise linear regression where all lags not significant at the 10 percent level of significance are deleted, which for most of the 1310 panel members results in no lag or just a single lag, and therefore it still leaves some degrees of freedom for the ADF test-statistic. The result is exhibited in Table 2, also including separate tests for the manufacturing sector and the private service sector, respectively.

Table 2. Unit root IPS-tests of firm-specific profits.

\begin{tabular}{lll}
\hline & Number of firms & IPS test-statistic \\
\hline All firms & 1310 & -2.553 \\
Manufacturing & 264 & -2.315 \\
Private services & 702 & -2.525 \\
\hline
\end{tabular}

Note: The critical values are approximately -1.75 and -1.68 at the 1 and 5 percent levels of significance, respectively $(\mathrm{N}=100, \mathrm{~T}=10)$, from Im et al. (2003). The test-statistics estimated in RATS by a stepwise linear regression procedure deleting lags in the augmented DF-test according to a 10 percent level of significance.

The conclusion is rather clear as the critical value for the 5 percent level of significance is approximately -1.68 according to the tabulated values in Im et al. (2003). For all firms and the two main private sectors exhibited in Table 2 - the IPS test-statistic is far below the relevant critical values (only tabulated up to $\mathrm{N}=100$ ), and hence the unit root hypothesis for firm profits is rejected.

According to the Industrial Organization literature, persistence in profits may be explained by entry barriers, where e.g. large firms may have enough market power to create barriers and consequently protect profits. Therefore, the panel data set including 
the 1310 firms is categorized according to firm size as measured by the number of employees and the IPS-test is applied to deciles of these data - which gives ten teststatistics used to verify whether there are differences concerning the unit root hypothesis by firm size.

The same procedure is followed when dividing the sample of firm data according to 'the minimum efficient scale'. In accordance with other studies, minimum efficient scale is defined as the $\log$ of the first deciles value of firm sales in each industry at the 4-digit NACE-code level. The minimum efficient production scale (MES) of each industry is expected to affect firm performance because a relatively high MES within an industry affects the likelihood of new firms entering the industry and therefore pure profits may be permanently higher in such industries.

Table 3. Unit root IPS-tests of firm-specific profits, panel data divided into deciles according to employment and minimum efficient scale $(\mathrm{N}=131, \mathrm{~T}=12)$.

\begin{tabular}{lll}
\hline Firms ranked according to: & Employment & Min. efficient scale \\
\hline Deciles & IPS test stat. & IPS test stat. \\
1 & -2.817 & -2.665 \\
2 & -2.508 & -2.617 \\
3 & -2.629 & -2.646 \\
4 & -2.674 & -2.425 \\
5 & -2.700 & -2.921 \\
6 & -2.502 & -2.639 \\
7 & -2.651 & -2.640 \\
8 & -2.527 & -2.371 \\
9 & -2.339 & -2.361 \\
10 & -2.182 & -2.244 \\
\hline
\end{tabular}

Note: The critical values are approximately -1.75 and -1.68 at the 1 and 5 percent levels of significance, respectively $(\mathrm{N}=100, \mathrm{~T}=10)$, from $\mathrm{Im}$ et al. (2003).

The IPS test-statistics from Table 3 reveal that ranking of firms according to employment and minimum efficient scale has no influence with respect to persistence in profits - in all cases the test indicates a rejection of the null hypothesis even at the 1 percent level of significance. These results are in accordance with a recent study by Yurtoglu (2004) 
using data for 172 Turkish firms, covering the time period 1985-1998. This study rejects that profits are non-stationary when applying the IPS unit root test. In addition, Yurtoglu (2004) finds that the same conclusion holds when testing the specific industries, where the unit root hypothesis is rejected for 11 cases out of a total of 13 industries.

\section{Testing for persistence in profits at the industry level}

As the conclusion from the firm-specific data is not in favor of a random walk behavior of profits, also aggregate industry data concerning average rates of return are investigated for a unit root. Calculating the average rate of return for a given industry comprising several hundred firms will most likely show up with a much more smooth pattern of profits over time and these are subsequently tested with respect to the unit root hypothesis. The industry-specific data cover 18 industries as summarized in Table 1 and the average rates of return are analyzed using the SURADF test methodology.

The first step in the analysis is to ascertain the lag length to be used in the test for a unit root, cf. the third term on the right-hand side of (10). This is done individually for the industries as standard DF/ADF-tests with no lag and a single lag, respectively, and thereafter testing the residuals for autocorrelation up to the order of two by a Lagrange Multiplier test. The results are reported in Table 4.

For three industries $(N=1,6$ and 10$)$ both the $\mathrm{DF}$ and $\operatorname{ADF}\{1\}$ tests show up with autocorrelation at least at the 10 percent level of significance. Twelve annual observations seem to be too short a time span to obtain reliable estimates concerning the DF-test for these three panel members as the residuals suffer from autocorrelation. Therefore, these industries are dropped from further tests for unit roots. For the remaining members, a lag length of zero is chosen, except for two panel members ( $\mathrm{N}=8$ and $\mathrm{N}=16$ ) where one lag performs best. 
Table 4. Lag length determination in individual industry-specific DF/ADF-tests.

\begin{tabular}{ll|lll|lll}
\hline & \multicolumn{3}{|c|}{ DF-test } & \multicolumn{3}{c}{ ADF $\{1\}$-test } \\
$\mathrm{N}$ & & DW & LM(2) & DW & LM(2) \\
\hline 1 & Primary industries & 1.10 & $5.99^{*}$ & $(0.05)$ & 2.33 & $6.02^{*}$ & $(0.05)$ \\
2 & Food, beverages & 1.71 & 1.89 & $(0.39)$ & 1.50 & 3.42 & $(0.18)$ \\
3 & Textiles & 2.14 & 0.88 & $(0.64)$ & 1.94 & 4.22 & $(0.12)$ \\
4 & Footwear, wood products & 1.90 & 1.08 & $(0.58)$ & 2.01 & 0.63 & $(0.73)$ \\
5 & Paper, printing & 2.07 & 2.92 & $(0.23)$ & 1.56 & 4.02 & $(0.13)$ \\
6 & Chemical products & 2.90 & $7.03^{*}$ & $(0.03)$ & 2.75 & $4.77^{* *}$ & $(0.09)$ \\
7 & Rubber and plastic products & 2.00 & 1.58 & $(0.45)$ & 1.66 & $6.98^{*}$ & $(0.03)$ \\
8 & Non-metallic mineral products & 0.74 & $4.83^{* *}(0.09)$ & 2.08 & 0.60 & $(0.74)$ \\
9 & Basic metals & 1.90 & 1.82 & $(0.40)$ & 1.98 & 3.72 & $(0.16)$ \\
10 & Machinery and equipment & 1.93 & $5.88^{*}$ & $(0.05)$ & 1.47 & $5.32^{* *}$ & $(0.07)$ \\
11 & Electrical equipment & 1.83 & 1.82 & $(0.40)$ & 1.52 & 1.85 & $(0.40)$ \\
12 & Transport equipment & 1.71 & 1.40 & $(0.24)$ & 2.20 & $5.36^{* *}$ & $(0.07)$ \\
13 & Furniture, toys & 2.09 & 0.46 & $(0.50)$ & 1.89 & 1.62 & $(0.45)$ \\
14 & Energy, construction & 2.04 & 0.15 & $(0.70)$ & 1.92 & 1.30 & $(0.52)$ \\
15 & Whole- and retail sales, repair & 2.01 & 0.13 & $(0.71)$ & 2.06 & 4.07 & $(0.13)$ \\
16 & Transport services & 2.48 & 1.98 & $(0.16)$ & 2.15 & 1.21 & $(0.55)$ \\
17 & Financial services, consultants & 2.01 & 0.09 & $(0.76)$ & 2.08 & 3.29 & $(0.19)$ \\
18 & Public reg. \& social service & 1.80 & 0.56 & $(0.45)$ & 1.93 & $5.62^{* *}$ & $(0.06)$ \\
\hline
\end{tabular}

Note: DW is the Durbin Watson test for first order autocorrelation and LM(2) is a Lagrange Multiplier test for second order autocorrelation with $p$-values in parenthesis. * indicates autocorrelation at least at the 5 percent level of significance - and $* *$ indicates the 10 n percent level of significance.

As a cross-check of the potential problems concerning autocorrelation for some of the panel members, the lag length is also investigated for via SUR regressions of the industry data. Similar DF/ADF tests as in Table 4 are done, but in this case each SUR estimation involves three industries, where the first system is for $\mathrm{N}=1,2$ and 3 , the next system is for the following three industries ( $\mathrm{N}=4,5$ and 6) etc. The results are exhibited in Table 5 where the dotted horizontal lines indicate the separate SUR estimations. Residuals from the individual industries are again evaluated with the $\operatorname{LM}(2)$-test for autocorrelation. 
Table 5. LM-tests for autocorrelation in panels of 3 members for industry-specific DF/ADF-tests (SUR estimation).

\begin{tabular}{|c|c|c|c|c|c|}
\hline \multicolumn{2}{|l|}{$\mathrm{N}$} & \multicolumn{2}{|c|}{$\begin{array}{l}\mathrm{LM}(2) \text {-test statistic } \\
\text { for the DF-test }\end{array}$} & \multicolumn{2}{|c|}{$\begin{array}{l}\mathrm{LM}(2) \text {-test statistic } \\
\text { for the } \mathrm{ADF}\{1\} \text {-test }\end{array}$} \\
\hline 1 & Primary industries & $6.13 *$ & $(0.05)$ & $6.13 *$ & $(0.05)$ \\
\hline 2 & Food, beverages & 2.24 & $(0.33)$ & 3.44 & $(0.18)$ \\
\hline 3 & Textiles & 0.88 & $(0.64)$ & 4.11 & $(0.13)$ \\
\hline 4 & Footwear, wood products & 1.00 & $(0.61)$ & 0.77 & $(0.68)$ \\
\hline 5 & Paper, printing & 3.44 & $(018)$ & 4.38 & $(0.11)$ \\
\hline 6 & Chemical products & $7.03 *$ & $(0.03)$ & $4.90 * *$ & $(0.08)$ \\
\hline 7 & Rubber and plastic products & 2.22 & $(0.33)$ & $7.02 *$ & $(0.03)$ \\
\hline 8 & Non-metallic mineral products & $4.89 * *$ & $(0.09)$ & 0.87 & $(0.65)$ \\
\hline 9 & Basic metals & 1.86 & $(0.39)$ & 4.44 & $(0.11)$ \\
\hline 10 & Machinery and equipment & $5.88^{*}$ & $(0.05)$ & $5.36 * *$ & $(0.07)$ \\
\hline 11 & Electrical equipment & 1.74 & $(0.42)$ & 2.09 & $(0.35)$ \\
\hline 12 & Transport equipment & 4.34 & $(0.11)$ & $5.54 * *$ & $(0.06)$ \\
\hline 13 & Furniture, toys & 0.95 & $(0.62)$ & 1.76 & $(0.41)$ \\
\hline 14 & Energy, construction & 0.70 & $(0.71)$ & 1.93 & $(0.38)$ \\
\hline 15 & Whole- and retail sales, repair & 4.11 & $(0.13)$ & 4.01 & $(0.13)$ \\
\hline 16 & Transport services & 2.05 & $(0.36)$ & 1.39 & $(0.50)$ \\
\hline 17 & Financial services, consultants & 0.82 & $(0.67)$ & 3.18 & $(0.20)$ \\
\hline 18 & Public regulation \& social service & 0.85 & $(0.65)$ & $5.58 * *$ & $(0.06)$ \\
\hline
\end{tabular}

Note: $\operatorname{LM}(2)$ is a Lagrange Multiplier test for second order autocorrelation with $p$-values in parentheses.

* indicates autocorrelation at least at the 5 percent level of significance - and ** indicates the 10 percent level of significance.

The conclusions from the SUR estimates in Table 5 are quite similar to the former results, as exactly the same three panel members still suffer from autocorrelation leaving 15 cross-section units to be included in the analysis. These 15 industries are then partitioned into 5 sections, each consisting of three panel members, which are used for the SURADF test. The systems have each the dimension $\mathrm{N}=3$ and $\mathrm{T}=12$ and cannot be expanded further due to the degrees of freedom deteriorating rapidly when estimating the residual variance/covariance matrix.

The five panels - each consisting of three industries as indicated by the dotted lines in Table 6 - are then estimated according to (10) and the respective test-statistics derived. 
The first column in Table 6 reports the SURADF test-statistic. The last part of the table is the simulated critical values at the 5 and 10 percent levels of significance. The simulation procedure for deriving the critical values has kindly been provided to us by M. Walace as the program also used for the analysis in Breuer et al. (2002). ${ }^{4}$ The critical values are derived for a null hypothesis of a unit root and hence no intercept and lagged level is included in the data simulations, see Breuer et al. (2002) for further arguments concerning procedures. The number of replications was set at 10,000 for each estimation, initially generating thirty-two observations, of which the first twenty observations are discarded in order to leave twelve observations as in the actual data set to be used for the calculation of critical values.

Table 6. SURADF unit root tests of aggregate industry-specific rates of return.

\begin{tabular}{|c|c|c|c|}
\hline & \multirow[t]{2}{*}{ SURADF test statistic } & \multicolumn{2}{|c|}{ Critical values } \\
\hline & & 0.05 & 0.10 \\
\hline \multicolumn{4}{|c|}{ Panels: } \\
\hline $\mathrm{N}=2$ & -2.67 & -4.20 & -3.60 \\
\hline $\mathrm{N}=3$ & 0.23 & -4.46 & -3.84 \\
\hline $\mathrm{N}=4$ & $-4.24 * *$ & -4.35 & -3.78 \\
\hline $\mathrm{N}=5$ & -3.36 & -4.20 & -3.78 \\
\hline $\mathrm{N}=7$ & -3.09 & -4.23 & -3.70 \\
\hline $\mathrm{N}=8$ & $-4.66^{*}$ & -4.47 & -3.89 \\
\hline $\mathrm{N}=9$ & -3.39 & -4.28 & -3.65 \\
\hline $\mathrm{N}=11$ & -1.70 & -4.18 & -3.58 \\
\hline $\mathrm{N}=12$ & -3.05 & -4.20 & -3.64 \\
\hline $\mathrm{N}=13$ & -1.95 & -4.17 & -3.59 \\
\hline $\mathrm{N}=14$ & $-3.94 * *$ & -4.34 & -3.74 \\
\hline $\mathrm{N}=15$ & -0.30 & -4.46 & .3 .83 \\
\hline $\mathrm{N}=16$ & 0.49 & -4.22 & -3.59 \\
\hline $\mathrm{N}=17$ & -2.07 & -4.20 & -3.61 \\
\hline $\mathrm{N}=18$ & -3.28 & -4.12 & -3.53 \\
\hline
\end{tabular}

Note: See Table 1 for a description of the panel members. * indicates rejection of a unit root hypothesis at least at the 5 percent level of significance - and ** indicates the 10 percent level of significance.

\footnotetext{
${ }^{4}$ The procedure is a RATS-program and has been modified to the present panel data set and all errors that might arise in this connection are of course the sole responsibility of the present authors. We thank Myles Wallace for the very helpful software supplied.
} 
Table 6 gives evidence of only three industries with stationary behavior at the 10 percent level of significance and in twelve cases the unit root hypothesis is not rejected. Thus, looking at industries as a whole there is evidence in favor of persistence in profits. This is quite the opposite conclusion reached as when using firm-specific data, cf. Tables 2 and 3. Therefore, the random walk hypothesis of firm profits cannot generally be rejected as revealed by testing the aggregate industry data for firm profits. Still, this conclusion has to be treated with caution as industry averages of rates of return have been used as well as the extremely short time dimension of the panel data set - although alternative lag length tests have been performed in order to minimize this potential problem.

\section{Conclusions}

In the present analysis, persistence in corporate performance is defined as a unit root behavior of firm profits, and hence if firm profits are really random walk processes, they are also non-predictable. Using accountancy information from Danish firms, this question is tested empirically by applying various unit root tests. Firm panel data sets are constructed with respect to measures of profits at both a firm-specific level as well as profits for industries aggregated at two-digit NACE codes. Although the number of firms in the available data set is very high, the time dimension is only twelve years covering the period 1990-2001. The latter is a potential problem in connection with unit root testing, but it is partly remedied by using panel data as the power of the panel tests is usually higher than single-equation tests. Recently presented test methodologies for unit roots in panel data have been applied, and when testing with data for firms, the hypothesis of a unit root in profits is generally rejected. This conclusion also holds when the data are categorized according to different criteria such as the size of the firms, which measures market power of incumbent firms, or by the degree of entry barriers measured by the 'minimum efficient production scale'. There seems to be no difference among the firms differentiated by these criteria and in all cases a unit root is rejected, i.e. the results are not in favor of persistence in profits. 
The calculated profit rates for the individual firms are, somewhat surprisingly, fluctuating relatively much even at an annual frequency. The high volatility of firm profits may be caused partly by less relevant factors such as accountancy procedures, tax rules, etc. Therefore, profit rates at industry levels are also calculated and applied to the SURADF panel unit root test procedure that allows for investigating individual panel members. When using these more smoothly evolving rates of return, the empirical evidence for persistence in profits is much more pronounced. For twelve out of fifteen industries the unit root hypothesis cannot be rejected even at the 10 percent level of significance, i.e. persistence in corporate performance is found for these cases, and for only a few cases a stationary alternative is indicated by the SURADF procedure. This discrepancy, which is found concerning a unit root in the data for profits at the industry level and no unit root for firm-specific profits, is not necessarily contradictory. Firms in a given industry are competing with each other and consequently with resulting shifts of market shares and profits among the firms involved even in the short run. From this, partly similar to Schumpeter's process of creative destruction, firm profits may appear very 'erratic' and volatile whereas the overall rate of return for the industry will be much more stable or smooth over time. Another interpretation or consequence of the contradictory results might be that when using industry-specific data, a unit root is revealed, and hence when modeling and estimating long-run profits of firms or industries, cointegration techniques have to be taken into consideration. Most likely, long-run cointegration relationships have to be estimated at the industry level of data aggregation, and the next step in the estimation procedure of a model for firm-specific profits might be to force a potential long-run relationship - from the industry data - upon the firm data when setting up e.g. an error-correction model. This topic of further empirical research seems relevant, but especially longer time series of the firm data are required in order to improve the analysis and estimation results. 


\section{References}

Breuer, J.B., R. McNown and M.S. Wallace (2001): Misleading Inferences from Panel Unit-Root Tests with an Illustration from Purchasing Power Parity. Review of International Economics, 9(3), 482-93.

Breuer, J.B., R. McNown and M. Wallace (2002): Series-specific Unit Root Tests with Panel Data. Oxford Bulletin of Economics and Statistics, 64.

Dreger, C. and R. Kosfeld (2003): Consumption and Income - Panel Econometric Evidence for West Germany. Applied Economics Quarterly, 49, 75-88.

Cubbin, J. and P. Geroski (1987): The Convergence of Profits in the Long Run: InterFirm and Inter-Industry Comparisons. The Journal of Industrial Economics, 35, 427-42.

Cubbin, J. and P. Geroski (1990): The persistence og Profits in United Kingdom, in Mueller, D.C. (ed.): The Dynamics of Company Profits: An International Comparison, Cambridge University Press, Cambridge.

Geroski, P. and A. Jacquemin (1988): The Persistence of Profits: A European Comparison. The Economic Journal, 98, 375-89.

Goddard, J.A. and J.O.S. Wilson (1996): Persistence of Profits for UK Manufacturing and Service Sector Firms. The Service Industries Journal, 16, 105-107.

Im, K.S., M.H. Pesaran and Y. Shin (2003): Testing for unit roots in heterogeneous panels. Journal of Econometrics, 115, 53-74.

Jenny, F. and A.P. Weber (1990): The Persistence of Profits, in Mueller, D.C. (ed.): The Dynamics of Company Profits: An International Comparison, Cambridge University Press, Cambridge. 
Lipczinsky, J. and J. Wilson (2001): Industrial Organization: An Analysis of Competitive Markets. Prentice Hall, UK.

Mueller, D. C. (1977): Persistence of Profits above the Norm. Economica, 44, 369-80.

Mueller, D. C. (1986): Profits in the Long Run. Cambridge University Press, Cambridge.

Mueller, D. C., Ed. (1990): The dynamics of company profits: An international comparison. Cambridge University Press, Cambridge.

Odagiri, H. and H. Yamawaki (1990): The persistence of Profits in Japan, in Mueller, D.C. (ed.): The Dynamics of Company Profits: An International Comparison, Cambridge University Press, Cambridge.

Österholm, P. (2004): Killing four unit root birds in the US economy with three panel unit root test stones. Applied Economics Letters; 11, 213-6.

Schol, F. (1990): The Persistence of Profits in the Long Run - A Critical Extension of Some Recent Findings. International Journal of Industrial Organization, 8, 385-404.

Schwalbach, J., Grasshoff, U. and T. Mahmood (1989): The Dynamics of Corporate Profits. European Economic Review, 33, 1625-1639.

Strauss, J and T. Yigit (2003): Shortfalls of Panel Unit Root Testing. Economic Letters, 81, 309-313.

Taylor, M.P. and L. Sarno (1998a): Real exchange rates under the recent float: unequivocal evidence of mean reversion. Economic Letters, 60, 131-7.

Taylor, M.P. and L. Sarno (1998b): The behavior of real exchange rates during the postBretton Woods period. Journal of International Economics, 46, 281-312. 
Wagner, G.A. (2003): Are state budget stabilization funds only the illustration of savings? Evidence from stationary panel data. The Quarterly Review of Economics and Finance, 43, 213-38.

Waring, G. F. (1996): Industry Differences in the Persistence of Firm-Specific Returns. American Economic Review, 86, 1253-1265.

Yurtoglu, B. B. (2004): Persistence of Firm-Level Profitability in Turkey. Applied Economics, 36, 1-11. 
Department of Economics:

Skriftserie/Working Paper:

2002:

WP 02-1 Peter Jensen, Michael Rosholm and Mette Verner: A Comparison of Different Estimators for Panel Data Sample Selection Models. ISSN 1397-4831.

WP 02-2 Erik Strøjer Madsen, Camilla Jensen and Jørgen Drud Hansen: Scale in Technology and Learning-by-doing in the Windmill Industry. ISSN 1397-4831.

WP 02-3 Peter Markussen, Gert Tinggaard Svendsen and Morten Vesterdal: The political economy of a tradable GHG permit market in the European Union. ISSN 13974831.

WP 02-4 Anders Frederiksen og Jan V. Hansen: Skattereformer: Dynamiske effekter og fordelingskonsekvenser. ISSN 1397-4831.

WP 02-5 Anders Poulsen: On the Evolutionary Stability of Bargaining Inefficiency. ISSN 1397-4831.

WP 02-6 Jan Bentzen and Valdemar Smith: What does California have in common with Finland, Norway and Sweden? ISSN 1397-4831.

WP 02-7 Odile Poulsen: Optimal Patent Policies: A Survey. ISSN 1397-4831.

WP 02-8 Jan Bentzen and Valdemar Smith: An empirical analysis of the interrelations among the export of red wine from France, Italy and Spain. ISSN 1397-4831.

WP 02-9 A. Goenka and O. Poulsen: Indeterminacy and Labor Augmenting Externalities. ISSN 1397-4831.

WP 02-10 Charlotte Christiansen and Helena Skyt Nielsen: The Educational Asset Market: A Finance Perspective on Human Capital Investment. ISSN 1397-4831.

WP 02-11 Gert Tinggaard Svendsen and Morten Vesterdal: CO2 trade and market power in the EU electricity sector. ISSN 1397-4831.

WP 02-12 Tibor Neugebauer, Anders Poulsen and Arthur Schram: Fairness and Reciprocity in the Hawk-Dove game. ISSN 1397-4831.

WP 02-13 Yoshifumi Ueda and Gert Tinggaard Svendsen: How to Solve the Tragedy of the Commons? Social Entrepreneurs and Global Public Goods. ISSN 1397-4831.

WP 02-14 Jan Bentzen and Valdemar Smith: An empirical analysis of the effect of labour market characteristics on marital dissolution rates. ISSN 1397-4831. 
WP 02-15 Christian Bjørnskov and Gert Tinggaard Svendsen: Why Does the Northern Light Shine So Brightly? Decentralisation, social capital and the economy. ISSN 13974831.

WP 02-16 Gert Tinggaard Svendsen: Lobbyism and $\mathrm{CO}_{2}$ trade in the EU. ISSN 1397-4831.

WP 02-17 Søren Harck: Reallønsaspirationer, fejlkorrektion og reallønskurver. ISSN 13974831.

WP 02-18 Anders Poulsen and Odile Poulsen: Materialism, Reciprocity and Altruism in the Prisoner's Dilemma - An Evolutionary Analysis. ISSN 1397-4831.

WP 02-19 Helena Skyt Nielsen, Marianne Simonsen and Mette Verner: Does the Gap in Family-friendly Policies Drive the Family Gap? ISSN 1397-4831.

2003:

WP 03-1 Søren Harck: Er der nu en strukturelt bestemt langsigts-ledighed I SMEC?: Phillipskurven i SMEC 99 vis-à-vis SMEC 94. ISSN 1397-4831.

WP 03-2 Beatrice Schindler Rangvid: Evaluating Private School Quality in Denmark. ISSN 1397-4831.

WP 03-3 Tor Eriksson: Managerial Pay and Executive Turnover in the Czech and Slovak Republics. ISSN 1397-4831.

WP 03-4 Michael Svarer and Mette Verner: Do Children Stabilize Marriages? ISSN 13974831.

WP 03-5 Christian Bjørnskov and Gert Tinggaard Svendsen: Measuring social capital - Is there a single underlying explanation? ISSN 1397-4831.

WP 03-6 Vibeke Jakobsen and Nina Smith: The educational attainment of the children of the Danish 'guest worker' immigrants. ISSN 1397-4831.

WP 03-7 Anders Poulsen: The Survival and Welfare Implications of Altruism When Preferences are Endogenous. ISSN 1397-4831.

WP 03-8 Helena Skyt Nielsen and Mette Verner: Why are Well-educated Women not Fulltimers? ISSN 1397-4831.

WP 03-9 Anders Poulsen: On Efficiency, Tie-Breaking Rules and Role Assignment Procedures in Evolutionary Bargaining. ISSN 1397-4831.

WP 03-10 Anders Poulsen and Gert Tinggaard Svendsen: Rise and Decline of Social Capital - Excess Co-operation in the One-Shot Prisoner's Dilemma Game. ISSN 13974831. 
WP 03-11 Nabanita Datta Gupta and Amaresh Dubey: Poverty and Fertility: An Instrumental Variables Analysis on Indian Micro Data. ISSN 1397-4831.

WP 03-12 Tor Eriksson: The Managerial Power Impact on Compensation - Some Further Evidence. ISSN 1397-4831.

WP 03-13 Christian Bjørnskov: Corruption and Social Capital. ISSN 1397-4831.

WP 03-14 Debashish Bhattacherjee: The Effects of Group Incentives in an Indian Firm - Evidence from Payroll Data. ISSN 1397-4831.

WP 03-15 Tor Eriksson och Peter Jensen: Tidsbegränsade anställninger - danska erfarenheter. ISSN 1397-4831.

WP 03-16 Tom Coupé, Valérie Smeets and Frédéric Warzynski: Incentives, Sorting and Productivity along the Career: Evidence from a Sample of Top Economists. ISSN 1397-4831.

WP 03-17 Jozef Koning, Patrick Van Cayseele and Frédéric Warzynski: The Effects of Privatization and Competitive Pressure on Firms' Price-Cost Margins: Micro Evidence from Emerging Economies. ISSN 1397-4831.

WP 03-18 Urs Steiner Brandt and Gert Tinggaard Svendsen: The coalition of industrialists and environmentalists in the climate change issue. ISSN 1397-4831.

WP 03-19 Jan Bentzen: An empirical analysis of gasoline price convergence for 20 OECD countries. ISSN 1397-4831.

WP 03-20 Jan Bentzen and Valdemar Smith: Regional income convergence in the Scandinavian countries. ISSN 1397-4831.

WP 03-21 Gert Tinggaard Svendsen: Social Capital, Corruption and Economic Growth: Eastern and Western Europe. ISSN 1397-4831.

WP 03-22 Jan Bentzen and Valdemar Smith: A Comparative Study of Wine Auction Prices: Mouton Rothschild Premier Cru Classé. ISSN 1397-4831.

WP 03-23 Peter Guldager: Folkepensionisternes incitamenter til at arbejde. ISSN 1397-4831.

WP 03-24 Valérie Smeets and Frédéric Warzynski: Job Creation, Job Destruction and Voting Behavior in Poland. ISSN 1397-4831.

WP 03-25 Tom Coupé, Valérie Smeets and Frédéric Warzynski: Incentives in Economic Departments: Testing Tournaments? ISSN 1397-4831.

WP 03-26 Erik Strøjer Madsen, Valdemar Smith and Mogens Dilling-Hansen: Industrial clusters, firm location and productivity - Some empirical evidence for Danish firms. ISSN 1397-4831. 
WP 03-27 Aycan Çelikaksoy, Helena Skyt Nielsen and Mette Verner: Marriage Migration: Just another case of positive assortative matching? ISSN 1397-4831.

2004:

WP 04-1 Elina Pylkkänen and Nina Smith: Career Interruptions due to Parental Leave - A Comparative Study of Denmark and Sweden. ISSN 1397-4831.

WP 04-2 Urs Steiner Brandt and Gert Tinggaard Svendsen: Switch Point and First-Mover Advantage: The Case of the Wind Turbine Industry. ISSN 1397-4831.

WP 04-3 Tor Eriksson and Jaime Ortega: The Adoption of Job Rotation: Testing the Theories. ISSN 1397-4831.

WP 04-4 Valérie Smeets: Are There Fast Tracks in Economic Departments? Evidence from a Sample of Top Economists. ISSN 1397-4831.

WP 04-5 Karsten Bjerring Olsen, Rikke Ibsen and Niels Westergaard-Nielsen: Does Outsourcing Create Unemployment? The Case of the Danish Textile and Clothing Industry. ISSN 1397-4831.

WP 04-6 Tor Eriksson and Johan Moritz Kuhn: Firm Spin-offs in Denmark 1981-2000 Patterns of Entry and Exit. ISSN 1397-4831.

WP 04-7 Mona Larsen and Nabanita Datta Gupta: The Impact of Health on Individual Retirement Plans: a Panel Analysis comparing Self-reported versus Diagnostic Measures. ISSN 1397-4831.

WP 04-8 Christian Bjørnskov: Inequality, Tolerance, and Growth. ISSN 1397-4831.

WP 04-9 Christian Bjørnskov: Legal Quality, Inequality, and Tolerance. ISSN 1397-4831.

WP 04-10 Karsten Bjerring Olsen: Economic Cooperation and Social Identity: Towards a Model of Economic Cross-Cultural Integration. ISSN 1397-4831.

WP 04-11 Iben Bolvig: Within- and between-firm mobility in the low-wage labour market. ISSN 1397-4831.

WP 04-12 Odile Poulsen and Gert Tinggaard Svendsen: Social Capital and Market Centralisation: A Two-Sector Model. ISSN 1397-4831.

WP 04-13 Aditya Goenka and Odile Poulsen: Factor Intensity Reversal and Ergodic Chaos. ISSN 1397-4831.

WP 04-14 Jan Bentzen and Valdemar Smith: Short-run and long-run relationships in the consumption of alcohol in the Scandinavian countries.

ISBN 87-7882-010-3 (trykt); ISBN 87-7882-011-1 (online). 
WP 04-15 Jan Bentzen, Erik Strøjer Madsen, Valdemar Smith and Mogens Dilling-Hansen: Persistence in Corporate Performance? Empirical Evidence from Panel Unit Root Tests.

ISBN 87-7882-012-X (trykt); ISBN 87-7882-013-8 (online). 